Indonesian Aquaculture Journal, 15 (2), 2020, 77-83

Available online at: http://ejournal-balitbang.kkp.go.id/index.php/iaj

\title{
EFFECT OF VARIOUS CRYOPROTECTANTS ON PRESERVATION OF BLACK TIGER Penaeus monodon SHRIMP SPERMATOZOA
}

\author{
Rosmiati", Ike Trismawanti, and Samuel Lante \\ Research Institute for Coastal Aquaculture and Fisheries Extension \\ Jl. Makmur Dg. Sitakka No.129, Maros 90512, South Sulawesi, Indonesia
}

(Received: May 6, 2019; Final revised: 23 June 23, 2020; Accepted: June 26, 2020)

\begin{abstract}
The development of cryopreservation technique on tiger shrimp Penaeus monodon broodstock spermatophore has been carried out to support the artificial insemination. This study aims to determine the effect of three cyoprotectants (methanol, dimetylsulphoxide (DMSO), and glycerol) for long term storage of tiger shrimp Penaeus monodon spermatozoa. Spermatophores were collected from the wild broodstocks through electrical shock. Spermatozoa were obtained by homogenizing the spermatophores using a Radnoti micro homogenizer in Ca-free saline solution containing one of three cryoprotectans (methanol, dimetylsulphoxide, and glycerol) separately at the concentration of $5 \%$ One $\mathrm{mL}$ of each cryoprotectant containing spermatozoa with the density of $1.02 \times 10^{6} \mathrm{cell} / \mathrm{mL}$ was transferred into a cryovial and cryopreserved at room temperature, $-20^{\circ} \mathrm{C}$ and $-196^{\circ} \mathrm{C}$ for 5,10 , and 30 days. The apparent sperm viability (ASV) of cryopreserved spermatozoa was monitored after treated. Thawing of cryopreserved spermatozoa was carried out in a $30^{\circ} \mathrm{C}$ wáter bath for two minutes. The result showed that the best apparent sperm viability was obtained at the using of glycerol at $-196^{\circ} \mathrm{C}$ in liquid nitrogen, even after the thirty days of cryopreservation time period with the ASV of $0.82 \times 10^{6} \mathrm{cell} / \mathrm{s} / \mathrm{mL}(80.39 \%$. Meanwhile two other cryoprotectans displayed the ASV of $0.54 \times 10^{6} \mathrm{cell} / \mathrm{s} / \mathrm{mL}\left(56.86 \%\right.$, and $0.23 \times 10^{6}$ cell $/ \mathrm{mL}(22.55 \%$. for DMSO and methanol, respectively. In turn, the control showed the lowest ASV with the ASV of $0.01 \times 10^{6}$ cells $/ \mathrm{mL}(1.27 \%$. The ASV showed by this glycerol exhibited asignificant difference $(P<0.05)$ to that of methanol, DMSO, and control.
\end{abstract}

\section{KEYWORDS: cryoprotectant; Penaeus monodon; spermatozoa; temperature}

\section{INTRODUCTION}

The tiger shrimp domestication process still has several constrains including the very low number of mating spawner from culture in the tank so that the eggs fertility could not be yielded (Lante \& Laining, 2016). One of the alternatives which can be achieved to improve the eggs fertility of tiger shrimp is through artificial insemination (AI) technique. The Al had been carried out by Research Institute for Brackish water Aquaculture and Fisheries Extension (RIBAFE) and given a good result particularly on the wild shrimp broodstock in 2014. Nevertheless, there has been often occurred a constrain in the applying of this Al such as un-sincronized gonad maturation between male and female broodstock as well as spermatophore

\footnotetext{
\# Correspondence: Research Institute for Coastal Aquaculture and Fisheries Extension. JI. Makmur Dg. Sitakka No.129, Maros 90512, South Sulawesi, Indonesia.

Tel. + 62411371544

E-mail: emirosmiati@yahoo.com
}

supplying (donor) and molting cycle of female broodstock (receiver).

To overcome this problem, it is required cryopreservation technique to preserve spermatophore at the time of female broodstock ready to be spawned. Study on cryopreservation particularly spermatozoa has been started since 1957 and more than 230 aquatic organism species have been investigated (Dong et al., 2007). The successful of sperm cryopreservation technique has been reported on more than 200 spesies (Figel \& Tiersch, 1997; Tiersch, 2000). However, only a limited number of reports exist on successful cryopreservation of Shrimp (Bart et al., 2006). Cryopreservation of spermatophore of tiger shrimp Penaeus monodon using various of cryoprotectants such as methanol $(\mathrm{MeOH})$, dimetylsulphoxide (DMSO), and ethylenglycol has been also reported. Nevertheless, their effects on the survival rate of sperm cells still gave a various result (Gwo, 2000; Wayman \& Tiersch, 2000; Chao \& Liao, 2001). 
The successful of spermatophore cryopreservation is determined by several factors such as extender, cryoprotectant, dilution ratio, freezing, and thawing rate as well as extender solution (Billard et al., 1995). The aims of this research was to determine the effect of three cyoprotectants (methanol, dimetylsulphoxide (DMSO), and glycerol) for cryopreservation of tiger shrimp Penaeus monodon spermatozoa. The best cryoprotectant obtained will be used for spermatophore cryopreservation of tiger shrimp broodstock in suppliying of spermatophore for artificial insemination.

\section{MATERIALS AND METHODS}

This study was conducted on the tiger shrimp breeding Station of Research Institute for Brackish Water Aquaculture and Fisheries Extension (RIBAFE)Barru District South Sulawesi Province. Spermato phores were collected from wild male broodstock which is catched from Aceh waters. Extender was used from Ca-free saline solution. Meanwhile, there are three kinds of cryoprotectants used i.e. dimetylsulphoxide (DMSO), methanol ( $\mathrm{MeOH})$, and glycerol solution.

\section{Male Broodstock Maturation}

Mature male of tiger shrimp Penaeus monodon with the body weight of 80 to $102 \pm 8.55 \mathrm{~g}$ and the body length of 19.5-21.9 $\pm 1.5 \mathrm{~cm}$ were selected based on their health and physical conditions. The selected shrimp were individually tagged using labeled plastic tags around the eyestalk and then reared in the maturation tank $3.0 \mathrm{~m}^{3}$ in volume with the density of 15 ind./tank. Water salinity, temperature, and water depth were maintained at $32 \% 35 \% 28{ }^{\circ} \mathrm{C}-29^{\circ} \mathrm{C}$, and $50 \mathrm{~cm}$, respectively. During rearing period, males broodstock were fed fresh feed consisted of squid, marine bloodworms, and oyster at amount of $15 \%$ of body weight, three times a day at 06:00, 12:00, and 18:00. Every day all tanks were syphoned and exchanged the water at amount level of $80 \%$

\section{Collection of Spermatophore}

The matured males indicated with a clear white swelling around the coxae at the base of the fifth walking leg were selected from the maturation tank. The selected males were measured their weight and length. Spermato phores were taken out through electrical shock using transformer set up at $5 \mathrm{~mA}$ and 8$12 \mathrm{~V}$ following the protocol as described by Sandifer et al. (1984). The transformer was connected with an electrode placed near the gonophores at the base of the 5 th pereiopodsa applied usually for two seconds. The eletrical shock stimulates contraction surround- ing the terminal ampullae expelling a single spermatophore from each gonophore. Spermatophores were removed with forceps and placed into an eppendorf tube filled with $1 \mathrm{~mL}$ of Ca-free saline solution known its weight. Other to prevent infection, a small drop of lodin 5\% was applied to the genital pore of the tested shrimp. The males were then reared back in the maturation tank.

\section{The Observation on Spermatophore and Spermatozoa}

The released spermatophore was weight using an elecrical balance (Sartorius, Germany). Subsequently, to release spermatozoa, the spermatophore was manually homogenized with Ca-free saline solution in a glass tissue grinder (Radnoti, USA). The spermatozoa observation was tested with staining technique using ethylene blue. A ten $\mu \mathrm{L}$ of ethylene blue were added into $50 \mu \mathrm{L}$ sperm suspension. Briefly, $10 \mu \mathrm{L}$ of this spermatozoa suspension were aspirated into a pipette, put on a haemocytometer and covered by coverslip. Number of spermatozoa was calculated under a microscope with a 40x objective (Olympus DP2I, Japan). The sperm cells were snapped and counted the number using Image I software.

The estimation of sperm cells number was calculated using the equation as followed:

$$
\text { The sperm cell quantity }(\text { cell } / \mathrm{mL})=\sum \mathrm{n} \times \mathrm{p} \times 10^{4}
$$

Note:

$\mathrm{N}=$ Total of sperm cells

$p=$ Dilution

Apparent sperm viability (ASV) post cryopreservation was counted by the following formula:

$$
\text { ASV }\left(\%=\sum \frac{n i}{n j} \times 100\right.
$$

\footnotetext{
Note:

$\mathrm{ni}=$ Sperm cells at the observation time

$\mathrm{nj}=$ Total of sperm cells initial number (fresh)
}

Characterization of the sperm cell was observed for the number of total sperm cell and percentage of normal cell. The cells with spherical body shape and straight and elongate spike was considered as normal cell, while sperm cells with irregular form and bent, double, or missing spike was considered as abnormal cell (Talbot et al., 1989).

\section{Cryopreservation of Spermatozoa}

Prior to cryopreservation, spermatozoa were separately stocked with the density of $1.02 \times 10^{6}$ cells/ $\mathrm{mL}$ in $50 \mathrm{~mL}$ of cryoprotectant solution (methanol 
(M), dimetylsulphoxide (D), and glycerol (G)) at the concentration of $5 \%$ in Ca-free saline solution. The similar spermatozoa were also stocked into $50 \mathrm{~mL}$ of Ca-free saline solution only as the control (S). One $\mathrm{mL}$ of each sperm-cryo protectant solution was transferred into cryoviallabeled according to the cryoprotectant code (M, D, G, and S) performed with 10 replicates. The cryovials containing spermatozoa were cryopreserved at room temperature, $-20^{\circ} \mathrm{C}$ and $-196^{\circ} \mathrm{C}$ in liquid nitrogen. Sperm cells cryopreserved at $-20^{\circ} \mathrm{C}$ previously kept at the temperature of $4^{\circ} \mathrm{C}$ $5^{\circ} \mathrm{C}$ for one hour. Similar to sperm cells cryopreserved at $-20^{\circ} \mathrm{C}$, sperm cells cryopreesrved at $-196^{\circ} \mathrm{C}$ in liquid nitrogen, it was kept at the temperature $4^{\circ} \mathrm{C}$ $5^{\circ} \mathrm{C}$ for one hour, $-20^{\circ} \mathrm{C}$ for overnight and continued to $-80^{\circ} \mathrm{C}$ for overnight to prevent sperm cell shock.

\section{Viability Monitoring of Cryopreserved Sperm}

The viability of cryopreserved sperm was monitored at 5,10 , and 30 days of cryopreservation period. To determine the viability of cryopreserved sperm, the samples were thawed at a $30^{\circ} \mathrm{C}$ water bath for two minutes. When the sperm suspensions melted completely, the viability of sperm cells was determined using the method mentioned before.

\section{RESULTS AND DISCUSSION}

The wild tiger shrimps Penaeus monodon used were 20 shrimps with weight and length ranged from 85$107 \mathrm{~g}$ and 18.0-22.5 cm, respectively. The weight, length, number and weight of spermatophore were summarized in Table 1.

Among wild shrimp, 20 of the 30 shrimp given an electrical shock presented spermatophore, commonly carrying two spermatophores with the average weight of $0.08 \mathrm{~g}$ (Table 1). From the Table 1, it can be seen that there was no correlation between shrimp weight and spermatophore weight. For example, in shrimp weight of 85 and $107 \mathrm{~g}$ the spermatophores weight of $0.08 \mathrm{~g}$ and $0.06 \mathrm{~g}$. In this study, the average spermatozoa number contained in one spermatophore was $4.75 \times 10^{6}$ cells $/ \mathrm{mL}$. Base on these data, it was revealed that spermatophore weight could not be indicator for spermatozoa number in the spermatophore.

The initial sperm cell density used was $1.02 \times 10^{6}$ cell $/ \mathrm{mL}$ and there was obtained $97.08 \%$ of normal sperm cells. Among four types of abnormal spermatozoa, the most frequent were missing spike. The similar result was investigated by Pratoomchat et al. (1993) reporting that spermatozoa without spike was a type abnormality which is the most frequent in
P. monodon namely more than $95 \%$ of the totality of abnormal spermatozoa. Nevertheless, an abnormal spermatozoa does not mean that it is infertile.

In each of the cryoprotectant tested, the highest sperm cell quantity and mean apparent sperm viability (ASV) cryopreserved at room temperature was observed at methanol $(\mathrm{MeOH}) 81.37 \pm 0.40 \%$ after treatment for five days and $55.88 \pm 0.12 \%$ after 10 days. The lowest was obtained at glycerol $37.52 \pm$ $0.64 \%$ after treatment for five days while, dimetylsulphxide (DMSO) and control (without cryoprotectant) showed the mean ASV of $80.39 \pm$ $0.30 \%$ and $38.23 \pm 0.34 \%$ after treatmen for five days. Nevertheless, after treatment for 30 days the highest mean ASV was exhibited by glycerol $24.51 \pm 0.98 \%$ and three other cryoprotectans (methanol, dimetylsulphoxide, and control) showed a drastically ASV decreasing ( $>90 \%$ even after 10 days and 30 days of treatment, spermatozoa without cryprotectant (control) exhibited lysis cells (Figure 1).

In turn, cryopreservation of spermatozoa at the temperature of $-20^{\circ} \mathrm{C}$ in glycerol showed the highest ASV at day $5(85.29 \pm 0.55 \%)$ even after treatment for $10(80.39 \pm 0.34 \%)$ and 30 days $(67.64 \pm 0.30 \%$. The lowest ASV at the same treatment time was exhibited by the control (without cryoprotectant) 1.96 $\pm 0.45 \% 1.27 \pm 0.44 \%$ and $0.98 \pm 0.65 \%$ respectively. Two other cryprotectants, methanol and dimetylsulphoxide also displayed a pure ASV of below $30 \%$ after treatment for five days $(20.58 \pm 0.61 \%$ and $26.47 \pm 0.55 \%, 10$ days $(7.84 \pm 0.34 \%$ and 7.84 $\pm 0.45 \%$ and 30 days $(2.94 \pm 0.61 \%$ and $2.94 \pm 0.50 \%$ (Figure 2).

The highest mean ASV was also shown by glycerol at the temperature of $-196^{\circ} \mathrm{C}$. The highest mean ASV observed after treatedfor 5,10 , and 30 days were $91.17 \pm 0.69 \% 89.22 \pm 0.56 \%$ and $80.39 \pm 0.45 \%$ respectively. Meanwhile, the lowest ASV was still exhibited by the control (without cryo protectant) 3.92 $\pm 0.44 \% 1.96 \pm 0.34 \%$ and $1.27 \pm 0.54 \%$ after treatment for 5,10 , and 30 days, respectively. Meanwhile, dimetylsulphoxide and methanol displayed the mean ASV of $77.45 \pm 0.30,70.58 \pm 0.96,56.86 \pm 0.05$ and $70.59 \pm 0.25,48.03 \pm 0.55$, and $22.55 \pm 0.27 \%$ respectively. These mean ASV shown by dimetylsulphoxide and methanol at the temperature of $-196^{\circ} \mathrm{C}$ were higher than these mean ASV indicated by these two cryoprotectans at the temperature of $-20^{\circ} \mathrm{C}$. Nevertheless, $\mathrm{MeOH}$ resulted a drastic decreasing of mean ASV $(67.60 \%)$ from day-5 until day-30 (Figure 3). 
Table 1. Weight, length, number and weight of spermatophore of wild black tiger P. monodon shrimp used for cryopreservation experiment

\begin{tabular}{cccc}
\hline $\begin{array}{c}\text { Weight } \\
\mathbf{( g )}\end{array}$ & $\begin{array}{c}\text { Length } \\
(\mathbf{c m})\end{array}$ & $\begin{array}{c}\text { Spermatophore } \\
\text { number }\end{array}$ & $\begin{array}{c}\text { Spermatophore } \\
\text { weight } \mathbf{( g )}\end{array}$ \\
\hline 85 & 21 & 2 & 0.08 \\
107 & 22.5 & 1 & 0.06 \\
94 & 21.4 & 2 & 0.08 \\
90 & 19.3 & 2 & 0.07 \\
85 & 20.7 & 2 & 0.07 \\
107 & 21.3 & 2 & 0.09 \\
99 & 20.4 & 2 & 0.08 \\
88 & 18 & 2 & 0.07 \\
84 & 22.3 & 2 & 0.09 \\
99 & 21 & 1 & 0.07 \\
84 & 20.2 & 2 & 0.08 \\
96 & 20.9 & 2 & 0.08 \\
107 & 22.5 & 2 & 0.06 \\
103 & 22.4 & 2 & 0.08 \\
98 & 21.7 & 2 & 0.07 \\
104 & 21.4 & 2 & 0.08 \\
92 & 21 & 2 & 0.08 \\
80 & 20.1 & 2 & 0.08 \\
90 & 20.6 & 2 & 0.08 \\
93 & 20.4 & 2 & 0.08 \\
\hline
\end{tabular}

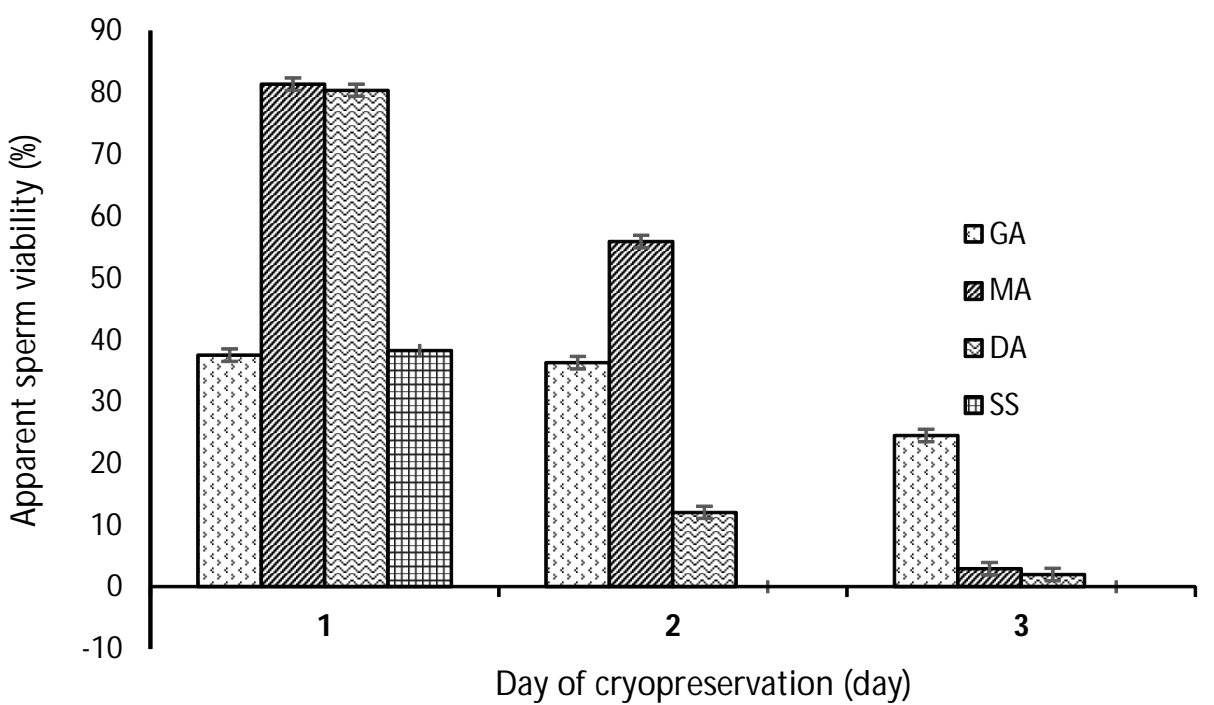

Figure 1. Mean apparent sperm viability (\%) treated for 5,10 , and 30 days with different cryoprotectans at the concentration of $5 \%$ at room temperature (mean \pm standard deviation). Note: GA (glycerol); MA (methanol); DA (dimetylsulphoxide); and SS (Ca-free saline solution/control). 


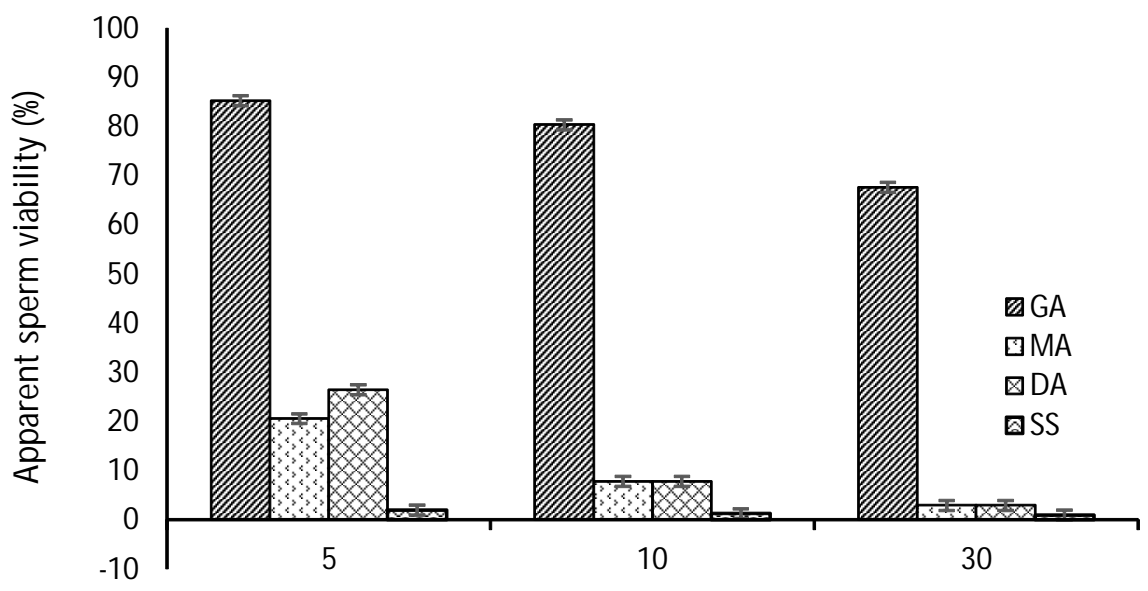

Day of cryopreservation (days)

Figure 2. Mean apparent sperm viability (\% treated for 5,10 , and 30 days with different cryoprotectans at the concentration of $5 \%$ at $20^{\circ} \mathrm{C}$ (mean \pm standard deviation). Note: GA (glycerol); MA (methanol); DA (dimetylsulphoxide); and SS (Ca-free saline solution/control).

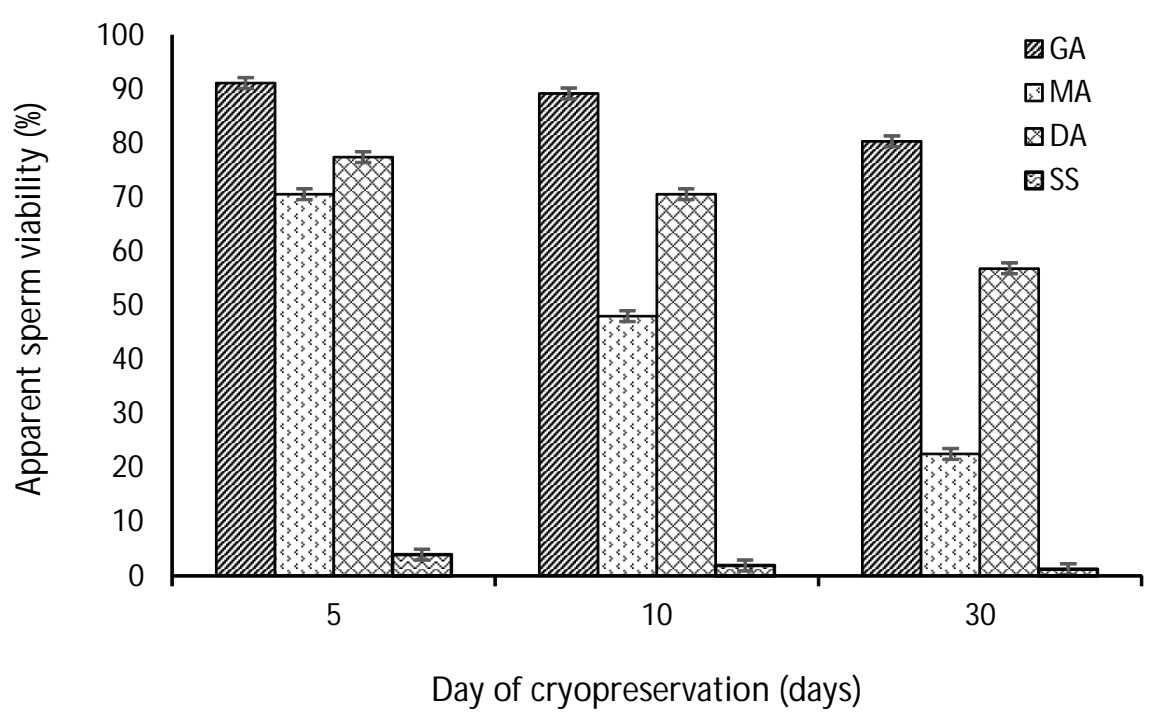

Figure 3. Mean apparent sperm viability (\% treated for 5,10 , and 30 days with different cryoprotectans at the concentration of $5 \%$ at $196^{\circ} \mathrm{C}$ (mean \pm standard deviation). Note: GA (glycerol); MA (methanol); DA (dimetylsulphoxide); and SS (Ca-free saline solution/control).

From Figure 1, 2, and 3 after treatment 30 days, it was obtained that sperm cells cryopreserved with glycerol and kept at the temperature of $-20^{\circ} \mathrm{C}$ and $-196^{\circ} \mathrm{C}$ and those cryopreserved with DMSO at $-196^{\circ} \mathrm{C}$ exhibited apparent cell viability > 50\% Among them, sperm cells cryopreserved using glycerol was found to be the highest $(80.39 \%$. This ASV value of spermatozoa treated with glycerol showed a significant difference $(P<0.05)$ to that of spermatozoa treated with methanol, dimetylsulphoxide and control (without cryoprotectant). The using of methanol, dimetylsulphoxide and glycerol as a cryoprotectant in this experiment, all of them displayed a significant difference to the control (without cryoprotectan). The similar result was showed by Chaves et al. (2014) reporting that Litopenaeus vannamei sperm criopreserved with $5 \%$ and $10 \%$ of glycerol and DMSO demonstrated the apparent sperm viability (ASV) of 
$78.37 \%$ and $97.42 \%$ or $>50 \%$ and there was not found any difference between glycerol and DMSO at the same concentration. It indicated that glycerol had a low toxic effect to shrimp sperm. However, the using of DMSO at the concentration $5 \%$ and the higher concentrations of $10 \% 15 \%$ and $20 \%$ resulted in the greater mortality in the criopreservation of Penaeus monodon sperm (Bart et al., 2006; Vuthiphandchai et al., 2007). The similar pattern was also obtained by Memon et al. (2012) who got the higher mortality when DMSO at the concentrations of 5\% 10\% 15\% and $20 \%$ was used for cryopreservation of another shrimp, Penaeus merguiensis sperm. The high sperm cell mortality in this study showed that $\mathrm{MeOH}$ at the concentration of $5 \%$ gave a negative effect on Penaeus monodon sperm. The same observation was also exhibited by Bart et al. (2006) at the similar species shrimp. There was obtained no any survival observed.

In Penaeus monodon sperm cells cryopreserved for 30 days with DMSO there was a significant decrease in apparent sperm viability (ASV) being more prominent from day-0 to day-5 with the decreasing of $22.50 \%$ giving a significant difference to day 10 and 30 . In turn, treatment with glycerol did not show any difference between day-5 and day-10. However, ASV in day-5 and day-10 significantly differed to that in day-30. The same observation was obtained in the study L. vannamei done by Chaves et al. (2014) reporting the decreasing of ASV aproximately $27 \%$ between day 15 and 30 although there was a difference in the freezing method. Fast freezing procedures is able to cause substantial damage to the cell and high sperm mortality suggesting that gradual cooling protocols must lead to better outcomes. However, in this study cooling to $4^{\circ} \mathrm{C}$ and freezing to $-196^{\circ} \mathrm{C}$ in two steps $\left(>4^{\circ} \mathrm{C}>-20^{\circ} \mathrm{C}>-196^{\circ} \mathrm{C}\right)$ has no any negative effect on Penaeus monodon sperm cells. However, the cooling rate was done manually in the refrigerator and freezer. Therefore, it might have a bit influence on the result obtained.

There are many factors affecting the success of cryopreservation technique such as cooling and freezing rate, type sand concentration of cryo protectant, final concentration of freezing, extender, and much more (Kartha, 1985; Ikhwanuddin et al., 2015). If freezing is very late, cells will be more dehydrated so that the concentration of electrolyte substance in the cell is to be high. In contrast, if fast freezing rates increase, the probability of intracellular ice formation will be leading to cryo-injuries. The choice of cryoprotectant is depended on the species in crustacean. According to Anchordoguy et al. (1988), compared to glycerol, sucrose, prolne, and trehalose, DMSO is a more effective cryoprotectant for marine shrimp Sicyoniaingentis. In turn, for tiger shrimp Penaeus monodon glycerol is a more effective cryoprotectant than DMSO at the concentration of $5 \%$ as the result of the present study. The high of sperm cells which lived at the glycerol treatment were due to the good protection on the presence of spermatozoa damage during the cryopreservation process (cryoinjury) in which glycerol itself had a function as permeating cryoprotectant.

\section{CONCLUSSION}

Based on this present study, the best cryoprotectant for cryopreservation of tiger shrimp Penaeus monodon spermatozoa for a long time storage was glycerol at the temperature of $-196^{\circ} \mathrm{C}$ in liquid nitrogen with the apparent sperm cell (ASV) of $80.39 \%$

\section{ACKNOWLEDGEMENTS}

This research was funded by Government of Indonesia through DIPA of Research Institute for Coastal Aquaculture T.A. 2016. Our great appreciation to staff at Shrimp Hatchery of Tiger Shrimp Breeding Instalation in Barru and to all people involved directly or indirectly during this study.

\section{REFERENCES}

Anchordoguy, T.J., Crowe, J.H., Griffin, F.J., \& Clark, W.H.Jr. (1988). Cryopreservation of sperm from the marine shrimp Sicyoniaingentis. Cryobiology, 25, 238-243.

Bart, A.N., Choosuk, S., \&Thakur, D. (2006). Spermato phore cryopreservation and artificial insemination of black tiger shrimp, Penaeus monodon (Fabricius). Aquaculture Resource, 37, 523-528.

Billard, R., Cosson, J., Crim, L.W., \& Suquet, M. (1995). Sperm physiology and quality. In: Bromage, N.R., Roberts, R.J., editors. Broodstock Management and Egg and Larval Quality. Cambridge University Press; Cambridge: 1995,p. 25-52.

Chao, N.H. \& Liao, L.C. (2001). Cryopreservation of finfish and shellfish gametes and embryos. Aquaculture, 197, 161-189.

Chaves, T.C.B., Fernandes, A.B., de Mello, M.R.B., \& Oshiro, L.Y. (2014). Cryopreservation and sprm storage of the white shrimp. Bol. Inst. Pesca. Sao Paulo, 40(1), 17-22.

Dong, Q., Hung, C., \& Tiersch. (2007), Control of sperm concentration is necessary for standardization of sperm cryopreservation in aquatic species: Evidence from Sperm Agglutinatio in Oysters. Cryobiology, 5, 87-98. 
Figiel, C.R. \& Tiersch, T.R. (1997). Comprehensive literature review of fish sperm cryopreservation. In Book of Abstracts of World Aquaculture'1997. Washington, USA, February 19-23, 1997, 155 pp.

Gwo, J.C. (2000). Cryopreservation of aquatic invertebrate semen: A review. Aquaculture Research, 31, 259-271.

Ikhwanuddin, M., Lan, S.S., Hamid, N.A., Fatihah, S.N., Azra, M.N., Aisah, A.S., \& Abol-M unafi, A.B. (2015). The embryonic development of orange mud crab, Scylla olivacea (Herbst, 1796) held in captivity. Iranian Journal of Fisheries Sciences, 14(4), 885-895.

Kartha, K.K. (1985). Meristem culture and gerplasm preservation. In Kartha, K.K. (Ed.). Cryopreservation of plant cell and organs. Florida: Cue Press, p. 116-134.

Lante, S. \& Laining, A. (2016). Application of artificial insemination for wild tiger shrimp, Penaeus monodon with different sources and numbers of spermatophore. Jurnal Riset Akuakultur, 11(2), 271280. (Indonesian with English abstract).

Memon, A.J., Talpur, A.D., Khan, M.L., Fariddudin, M.O., Safiah, J., Abol-Munafi, A.B., \& Ikhwanuddin, M. (2012). Optimization of spermatophores cryopreservation protocol of banana shrimp (Penaeus merguiensis (De Man, 1888). Journal of Animal and Veterinary Advances, 11(10), 688-1704.
Pratoomchat, B., Piyatiratitivorakul, S., Menasveta, P., \& Fast, A.W. (1993). Sperm quality of pondreared and wild-caught Penaeus monodon in Thailand. J. World Maricult. Soc., 24, 530-540.

Sandifer, P.A., Lawrence, A.L., Harris, S.G., Chamberlain, G.W., Stokes, A.D., \& Bray, W.A. (1984). Electrical stimulation of spermatophore expulsion in marine shrimp. Aquaculture, 41, 181-187.

Talbot, P., Howard, D., Leung-Trujillo, J., Lee, T.W., Li, W.Y., \& Ro, H. (1989). Characterization of male reproductive tract degenerative syndrome in captive penaeid shrimp Penaeus setiferus. Aquaculture, 78, 365-377.

Tiersch, T.R. (2000). Introduction. In Cryopreservation in aquatic species. Tiersch T.R. \& Mazik, P.M. (Eds.), p. 19-26. Baton Rouge, LA, USA: World Aquaculture Society.

Vuthiphandchai, V., Nimrat, S., Kotcharat, S., \& Bart, A. N. (2007). Development of a cryopreservation protocol for long-term storage of black tiger shrimp (Penaeus monodon) spermatophores. Theriogenology, 68, 1192-1199.

Wayman, W.R. \& Tiersch, T.R. (2000). Research method for cryopreservation of sperm. In Cryopreservation in aquatic species. Tiersch T.R. \& Mazik, P.M. (Eds.), p. 264-275. Baton Rouge. Louisiana, USA: World Aquaculture Society. 